\title{
タウリン欠乏と運動機能及び骨格筋老化との関連 〜タウリントランスポーターノックアウトマウスからの知見
}

\author{
伊 藤 崇 志
}

(福井県立大学生物資源学部)

タウリンは生体内の各臓器に高濃度に存在する含硫ア ミノ酸で，骨格筋には特に多く存在する。 タウリンの効 果として運動機能の向上や疲労回復の改善などが知られ ているが, 詳細は不明である。細胞内にはタウリンは 10-40 mM と高濃度に存在して, 細胞の浸透圧調節に主 要な役割を果たす “双性オスモライト”として機能して いる。一方で, 組織中のタウリンの欠乏により心筋症や 失明など種々の機能障害が起こることが知られている. 我々は細胞内へのタウリンの取り込みに関与するタウリ ントランスポーターを欠損するタウリントランスポー ターノックアウト (TauTKO) マウスを作製し, タウリ ン欠その各組織への影響を解析してきた。 TauTKOマ ウスにおいては, 組織中の夕ウリン含量の減少は心臓や 骨格筋, 眼で特に顕著で, $99 \%$ 程度の減少がみられた。 TauTKOマウスは野生型に比べて体重が軽く, 心筋症や 失明など，これまでネコなどの動物で報告されたのと同 様の組織異常がみられ, 1 年程度の寿命の短縮も認めら れた，その他，脳神経の発達異常なども報告されている。 加えて, 骨格筋の形態学的異常や運動機能の低下が認め られた。今回の発表では, TauTKOマウスにおける運動 機能や老化に関連した知見を詳細に紹介したい.

前述のように, 強制水泳試験やトレッドミル走行試験 の結果から, TauTKOマウスでは運動耐容能が顕著に低 下することが分かった，骨格筋の組織学的解析からは, 骨格筋繊維の萎縮がみられた。電子顕微鏡レベルでの解 析では, 筋繊維の微細構造の大きな乱れが部分的に認め られ，運動機能低下への寄与が考えられた。一方で，卜 レッドミル走行後に血液中の乳酸及びグルコース濃度を 測定したところ, TauTKOマウスでは運動開始後早期に 血中グルコース濃度の低下が起こり, 乳酸濃度は急激に 上昇した。 また，ミトコンドリアの構造にも異常が認め られたり, 生化学的解析によりミトコンドリアの代謝活 性低下も認められたりしたことから, エネルギー産生の 低下も，運動機能低下の一因であると考えられた。

一方で, TauTKOマウスの寿命は, 野生型マウス寿命 と比較して短縮した。 また, 特にTauTKOマウス骨格筋
において細胞老化のマーカーであるサイクリンキナーゼ インヒビター, p16の発現立進が認められた。 それに加 えて, 老化に特徵的な組織学的変化が観察されたことか ら, タウリン欠乏による組織老化の促進が示唆された。

タウリン欠乏による運動機能低下や組織老化の原因を 探るために，TauTKOマウス骨格筋のトランスクリプ トーム解析を行った。 その結果, アミノ酸代謝やタンパ ク質合成, タンパク質フォールディングに関連した遺 伝子群の増加が認められた。 その中でも, 小胞体スト レス応答に関連する転写因子 XBP-1 や分子シャペロン Grp78の発現充進が認められた。転写因子XBP-1に関し ては, 活性をもつスプライシング型の発現上昇も認めら れた. XBP-1, Grp78ともにタンパク質レベルでの発現 増加も確認されたことから, タウリン欠乏により, タン パク質フォールディングに伴う小胞体ストレスの充進が 起こることが示唆された。

タウリンなどの “双性オスモライト”は細胞内の浸透 圧調節の他, タンパク質や核酸の構造維持にはたらくと の説が提唱されている。我々の実験で得られた結果から は, TauTKOマウスではタウリン欠乏によりタンパク 質フォールディングの異常が起きることが示されたこと から, タウリンがタンパク質の構造維持にはたらくこと が支持される。その他，我々は，運動機能やタンパク質 合成に主要な役割をになう AMPK P mTOR といったシ グナル伝達タンパクの発現低下も認めている．以上の知 見から, タウリン欠乏によって, タンパク質の不安定化 が引き金となり, 種々のシグナル伝達機能の低下もとも なって, 筋タンパクの合成調節の破たんやエネルギー調 節の破たんを来したことにより，運動能低下や老化促進 ヘとつながったものと考えられた.

以上, 我々の結果からタウリンの骨格筋機能の維持に 重要な機能が明らかになった。 今後のさらなる検討から, タウリン補充によって組織のタウリン欠乏を防ぐことに よる運動機能促進やサルコペニア予防効果が明らかにな ることが期待される。 